DOI: $10.2478 / \mathrm{v} 10025-008-0005-2$

JOURNAL OF WATER

AND LAND DEVELOPMENT

J. Water Land Dev. No. 11, 2007: 59-69

\title{
Hydrological analysis for meeting climate change effects and European Water Framework Directive targets
}

\author{
Erik P. QUERNER, Henry M. MULDER
}

Alterra, Centre for Water and Climate, P.O. Box 47, 6700 AC Wageningen, The Netherlands; e-mail: erik.querner@wur.nl

\begin{abstract}
The very wet conditions of recent years in Europe have made it clear that measures will have to be taken in this century to prevent flooding. The question is how to manage groundwater in order to reduce the anticipated increased hydrological risk. Furthermore the surface water quality in the Netherlands is insufficient to meet the standards of the Water Framework Directive. The required improvements are difficult to reach, because the diffuse loads of nutrients from agricultural land can not be easily reduced. This demands for innovative solutions with respect to improve the surface water quality. In this pilot study the focus is on the purification in reed fields and use it as well to reduce the effects of the anticipated climate change. An experimental evidence on a practical scale is lacking and therefore in the woodland area of Lankheet in the eastern part of the Netherlands, 3 ha has been planted with reeds to purify the river water. The aim of the study is further to store the purified water in the groundwater in order to reduce climate change effects. For the hydrological situation a scenario study was set up, using a regional hydrological model to simulate the groundwater flow together with the water flow in a network of water courses. The analysis will give knowledge on the multifunctional use of such a system.
\end{abstract}

Key words: flooding, groundwater, stream flow, surface water, Water Framework Directive, water storage

\section{INTRODUCTION}

The Netherlands was formed by the delta of the rivers Rhine and Meuse. About half the country is now below sea level (the low-lying part); the remainder is only slightly above sea level. Throughout the country the water table is quite shallow, in general less than $2.5 \mathrm{~m}$ below the soil surface. A dense network of engineered watercourses is needed to drain the land. The very wet conditions of recent years in Europe have made it clear that measures will have to be taken in this century to prevent flooding. As indicated in the recent published IPCC report (IPCC, 2007), the anticipated climate change will have a crucial effect on groundwater and 
surface water. The question is how to manage groundwater in order to reduce the anticipated increased hydrological risk.

The objectives of the European Water Framework Directive (WFD) focus on sustainable water use by protection and improvement of the surface and groundwater, using the river basin as the focal point. In a tentative study, the consequences of the WFD for agriculture in the Netherlands was carried out for nutrients and pesticides in fresh water ecosystems (VAN DER BOLT and LEENDERS, 2004). The results indicated that the surface water quality in the Netherlands is insufficient to meet the standards of the Water Framework Directive. The possible consequences of the Directive are considerable, in larger parts of the Netherlands arable land should be taken out of production, because the diffuse loads of nutrients from agricultural land cannot be easily reduced (VAN BAKEL, 2006). This situation demands for innovative solutions with respect to reduce the anticipated effects of climate change, and to improve the surface water quality on meeting the WFD targets.

In this paper we report on a project which is presently carried out in the Eastern part of the Netherlands. It's an experimental set-up in order to improve the water quality of the surface water and to reduce the effects of the anticipated climate change. We describe first the set up and verification of the SIMGRO model. Then a hydrological analysis of water conservation will be presented and finally the effect of the climate scenario on the stream flow.

\section{BACKGROUND}

The effects of climate change and meeting the target for the WFD demands for innovative solutions. In an experimental set-up the purification of the water in reed fields is monitored and investigated, together with the reduction of peak flows. A schematic layout of the set-up, the so-called Vereijken concept, is shown in Figure 1. An experimental evidence on a practical scale is lacking and therefore in the woodland area of Lankheet in the eastern part of the Netherlands, an area of 3 ha has been planted with reeds to purify the river water. Reed is able to take up nutrients and phosphorus, it is known that uptake of $\mathrm{P}$ could be as much as $50 \mathrm{~kg}$ per ha per year. The purified water can be stored in designated areas. Further benefit is to replenish the groundwater in order to recover the terrestic ecosystem from too dry conditions. Also the water can be retained in the reed fields and in the forest to prevent flooding downstream. A promising measure is also to periodically harvest the reeds to be used as bio fuel. Based on the analysis carried out in Lankheet tools will be developed for the hydrological feasibility of water storage and purifying reed lands in other parts of the Netherlands.

Climatologists anticipate that the climate in the near future (around 2050) will be warmer and wetter. The Dutch Royal Meteorological Institute predicted a set of climate change scenarios, based on moderate warmer or warmer conditions, based 


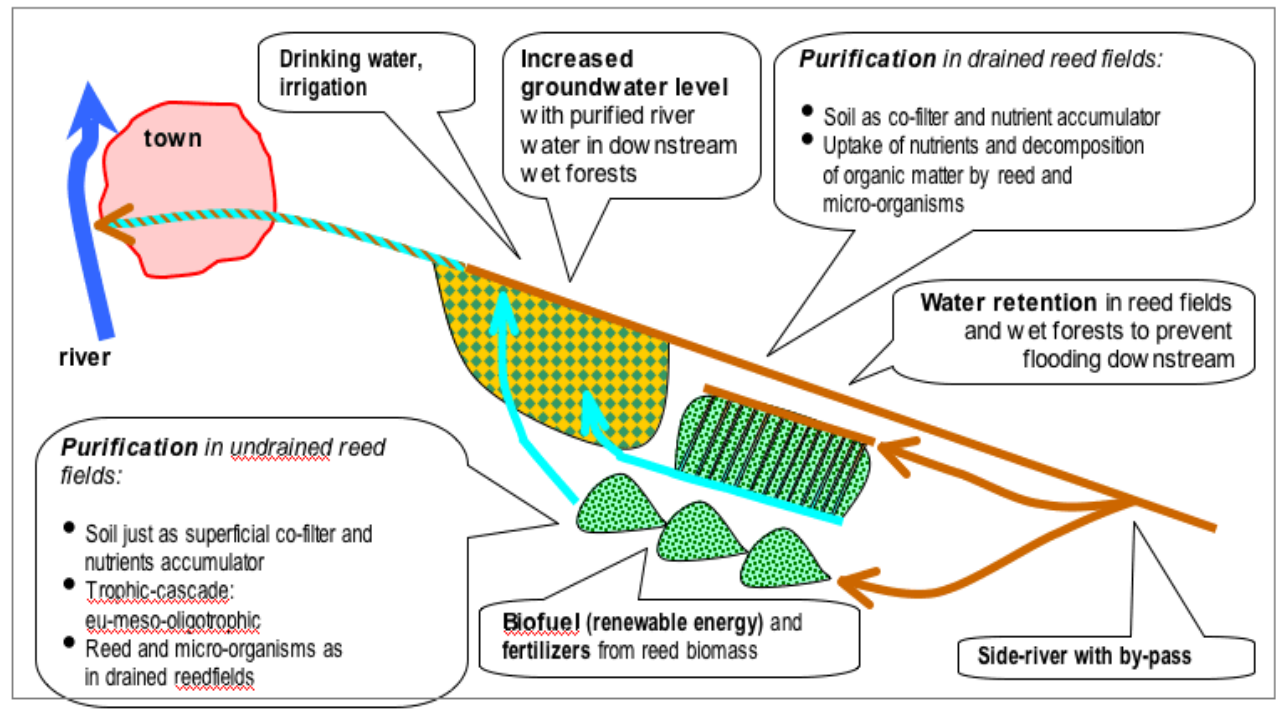

Fig. 1. Schematic layout of the experimental concept (VEREIJKEN and VAN DER WERF, 2007)

on the data and methods given in the $4^{\text {th }}$ IPCC report. The average temperature is expected to rise one or two degrees. Furthermore the air circulation could change resulting in more frequent easterly winds in summer, meaning dryer conditions. For a temperature rise of two degrees, including the change in air circulation, the so-called $\mathrm{W}+$ scenario, the average annual rainfall will decrease in summer by $19 \%$ and increase in winter by $14 \%$ (VAN DER HURK et al., 2006). The annual potential evapotranspiration will increase by $15 \%$. It is further expected that the rainfall in a period of 10 days will increase by $12 \%$ in winter and $10 \%$ in summer. Based on these predicted changes historical meteorological data on a daily base was transformed into a new series applicable for the period around 2050. Fife years of meteorological data on a daily basis were selected for the simulations with the hydrological model, being the period 1994-1999. The year 1998 was extreme wet, resulting in an average annual rainfall for this period of $863 \mathrm{~mm}$, for the climate change scenario this increases to $897 \mathrm{~mm}$ per year (increase of $4 \%$ ). The average potential evapotranspiration for grass was $539 \mathrm{~mm}$ per year and for the climate change scenario it increases to $620 \mathrm{~mm}$. In the 5 years high intensity rainfall events of $30-40 \mathrm{~mm} \cdot \mathrm{d}^{-1}$ occurred 6 times and events of $40-50 \mathrm{~mm} \cdot \mathrm{d}^{-1}$ occurred 2 times. 


\section{THE COMBINED SURFACE AND GROUNDWATER FLOW MODEL SIMGRO}

SIMGRO (SIMulation of GROundwater and surface water levels) is a distributed physically-based model that simulates regional transient saturated groundwater flow, unsaturated flow, actual evapotranspiration, sprinkler irrigation, stream flow, groundwater and surface water levels as a response to rainfall, reference evapotranspiration, and groundwater abstraction. To model regional groundwater flow, as in SIMGRO, the system has to be schematised geographically, both horizontally and vertically. The horizontal schematisation allows input of different land uses and soils per subregion, in order to model spatial differences in evapotranspiration and moisture content in the unsaturated zone. For the saturated zone various subsurface layers are considered. For a comprehensive description of SIMGRO, including all the model parameters readers are referred to VAN WALSUM et al. (2004) or QUERNER (2007).

\section{STUDY AREA AND SCHEMATIZATION}

The modelling area is located in the eastern part of the Netherlands, close to the German border, and covers $125 \mathrm{~km}^{2}$ (see Fig. 2) Also shown is the area of main interest, the Lankheet estate, being approximately $5 \mathrm{~km}^{2}$. The ground surface slopes from about $31 \mathrm{~m}+\mathrm{MSL}$ on the east side to about $22 \mathrm{~m}$ in the west side. The difference in height of about $9 \mathrm{~m}$ means that weirs were constructed in the past to control the water level and flow. The area consists of sandy soils in the upper parts with some clay in the stream valleys. Land use for the Lankheet estate is predominantly agricultural and forest. About $29 \%$ is in pasture, $10 \%$ is arable land, $55 \%$ woodland and $6 \%$ other.

For the SIMGRO model the groundwater system needs to be schematized by means of a finite element network. The network, comprising 16000 nodes, is spaced at about $25 \mathrm{~m}$ in the interest area and increases slowly to a spacing of $300 \mathrm{~m}$ at the model boundary. For the modelling of the surface water the basin is subdivided into 990 sub-basins. The interaction between groundwater and surface water is characterized by a drainage resistance. This resistance is derived from hydrological parameters and the spacing of the water courses. The groundwater system in the model consists of a single aquifer with under laying Miocene clay. For the aquifer the transmissivity varies between 25 and $300 \mathrm{~m} \cdot \mathrm{d}^{-1}$.

The Lankheet estate is situated south of the Buurser brook, as shown in Fig. 3. The estate dates back to the $12^{\text {th }}$ century. On the estate grasslands used to be flooded with water from the nearby brook. Flooding of the grass cover was an agricultural practise since the $10^{\text {th }}$ century in the Netherlands, where the sediments in 


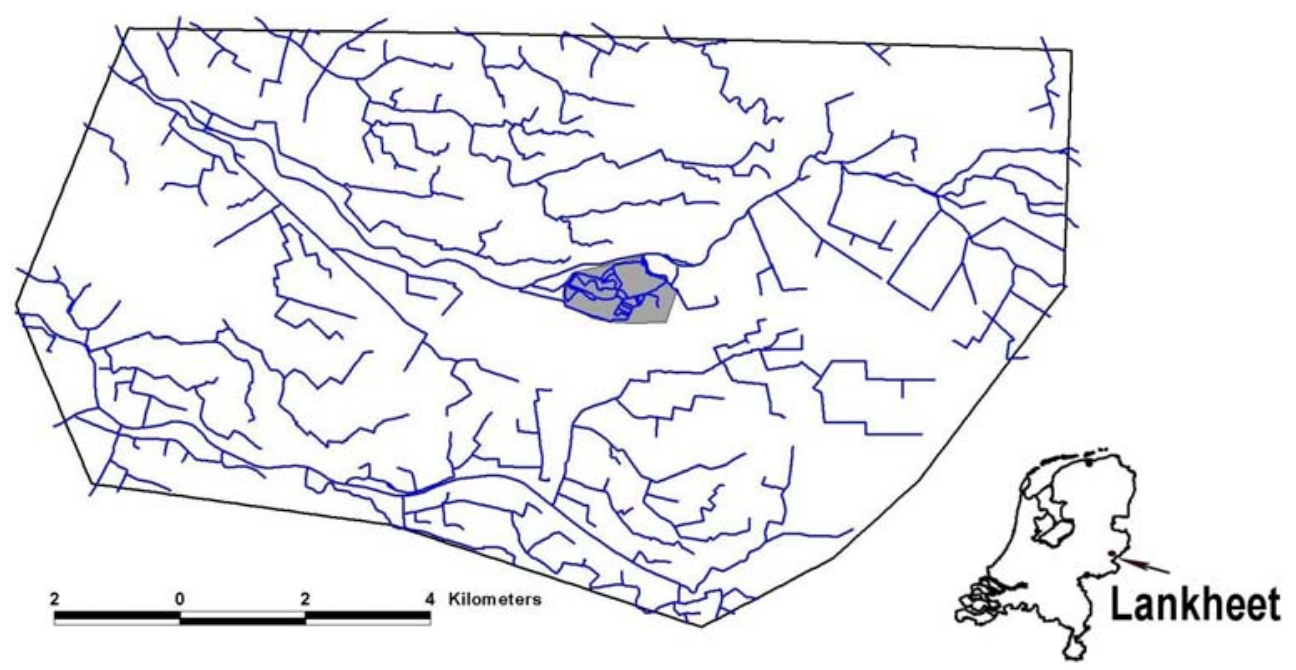

Fig. 2. Location of the modelling area and the main water courses in the eastern part of The Netherlands. The shaded area is the Lankheet estate

the water improve the fertility of the soil and thus means a higher crop production (hay). The water was applied in winter and early spring in order to stimulate also an earlier start of the growing season. This practice needed a dense network of ditches on the estate to distribute the water (see Fig. 3).

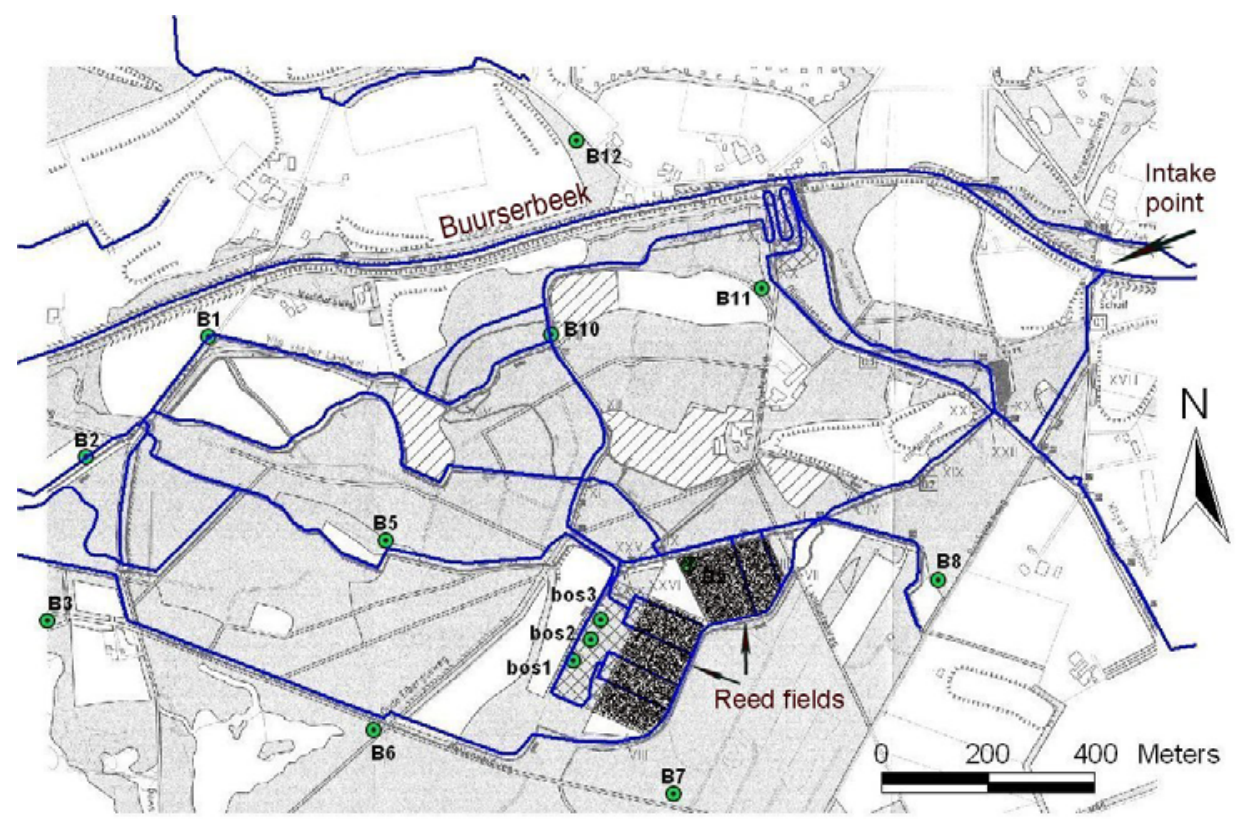

Fig. 3. Location of the Lankheet estate with its ditches, reed fields and piezometers 
Since the beginning of 2006 water is extracted from the brook and flows thru a number of reed fields. The intake point is shown in Fig. 3. The inflow to the fields is on average $50 \mathrm{l} \cdot \mathrm{s}^{-1}$. Approximately one day the water remains in the fields before it is pumped out. The water from the reed fields is flowing along different ditches over the estate and will be stimulated to infiltrate to the groundwater.

\section{SIMULATION RESULTS}

\section{PRESENT SITUATION}

For the verification of the model the simulations have been carried out for a period of 5 years (2002-2007). The results were compared with measured river discharge and groundwater levels. For the gauging station in the Buurserbeek the measured and calculated discharges compare well (MULDER et al., 2007). On the Lankheet estate 15 piezometers were installed to compare groundwater levels measured and calculated. When comparing phreatic groundwater levels, for 9 locations the difference in measured and calculated head is less than $0.2 \mathrm{~m}$. For 4 locations the difference is between 0.2 and $0.3 \mathrm{~m}$ and for 2 locations the difference is more than $0.3 \mathrm{~m}$. From experience differences less than $0.20 \mathrm{~m}$ can be regarded as a good agreement. Figure 4 shows the differences in groundwater levels for location bos2. The highest groundwater levels calculated are a bit lower than measured. These differences between measured and calculated results were regarded as small, so it was concluded that the model can be used to analyse measures and different meteorological conditions.

\section{EFFECT OF WATER INTAKE TO THE REED FIELDS}

Since the beginning of 2006 water is extracted from the nearby brook and flows thru the reed fields. The result of this water going thru the reed fields is an increased infiltration of water and thus higher groundwater levels. Figure 5 shows the difference in groundwater levels for the location bos2. The high groundwater levels in winter are about the same. In summer the water table used to be quite deep, but after water intake to the reed fields the water table is about $0.5-0.7 \mathrm{~m} \mathrm{hi}-$ gher and remains about less than $0.5 \mathrm{~m}$ below the soil surface. Figure 5 shows that the too dry conditions in summer on the estate can be easily reduced by the intake of water for the reed fields. 


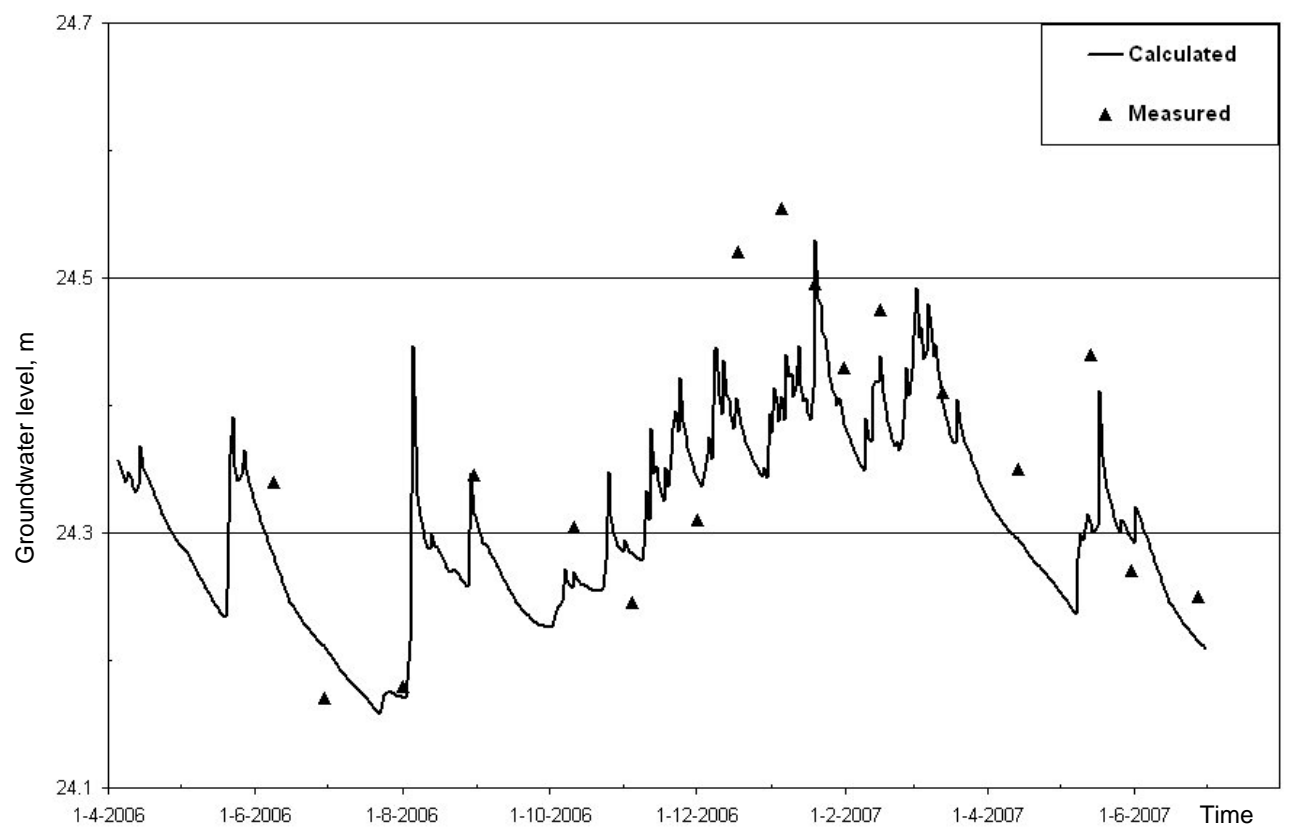

Fig. 4. Calculated and measured water table for piezometers bos2

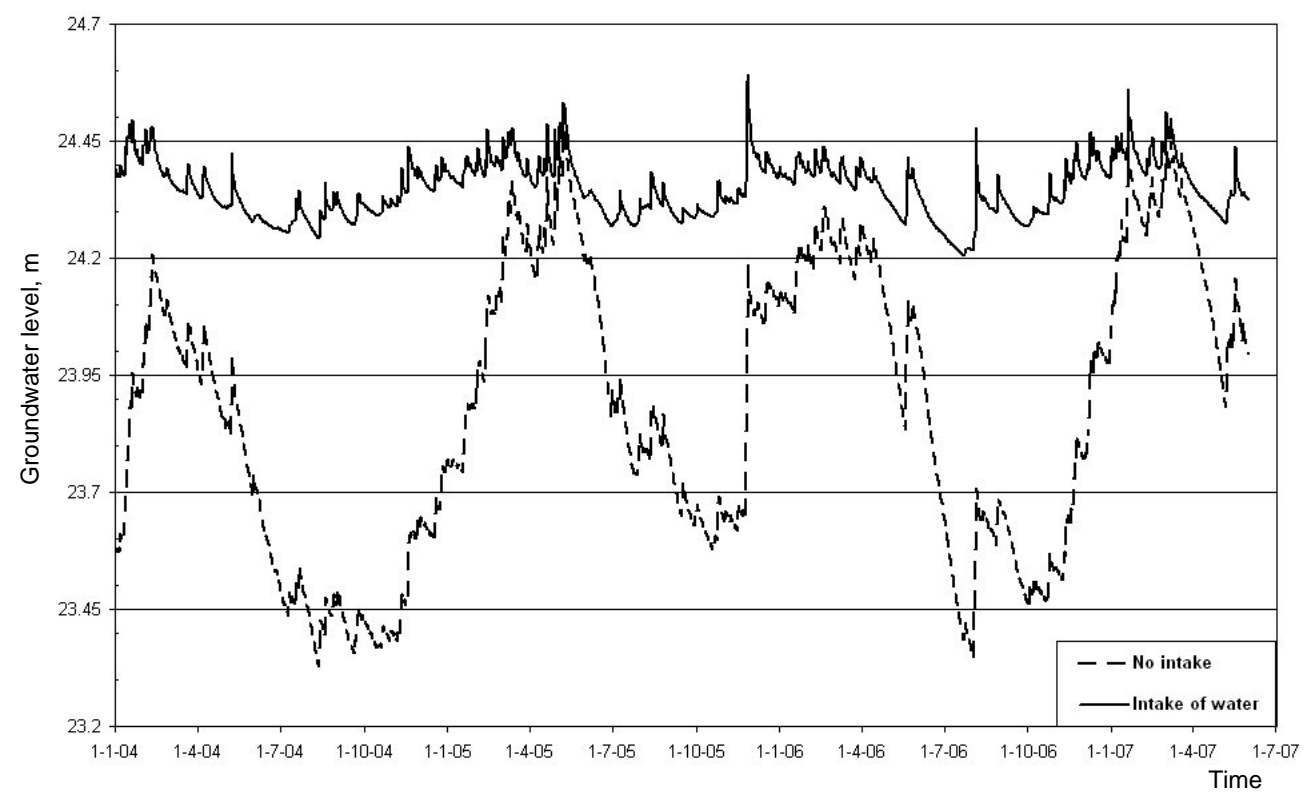

Fig. 5. Groundwater levels calculated with SIMGRO near piezometers bos2 (Fig. 3) before and after intake of water to the reed fields 


\section{EFFECT OF CLIMATE SCENARIO ON STREAM FLOWS}

Running the model for the present situation and the climate change scenario will show the differences in stream flows. The calculations were carried out for the meteorological years 1994-1999. For a closed sub-basin of $31 \mathrm{~km}^{2}$ within the modelling area the analysis was carried out. Figure 6 shows the stream flow of this sub-basin for the years 1997 and 1998, together with the change in stream flow. In winter the stream flow is higher (10-15\%), but in summer the flow is much smaller due to the reduced rainfall and the increased evapotranspiration. The reduction is as much as $40-50 \%$. The dryer conditions in the climate change scenario results in higher water storage capacities in the ground, resulting in an attenuation of the stream flow. The stream flows were also analysed in terms of frequency of exceedance, for the highest peak in this 5 year period the increase in flow was $15 \%$. For 5 occurrences in this period the increase was $8-10 \%$. Because of the relative short duration of the simulations (5 years) the calculations give a rough order of the changes in flow pattern, but a longer calculation period is needed to give a more precise answer. Simulations of basin response to climate change in the Netherlands reported some years ago (QUERNER, 2002), gave increases in peak flows in the order of 20 to $30 \%$, based on the previous set of climate change scenarios. In the present scenarios there is a lower increase in precipitation and the assumed evapotranspiration is higher.

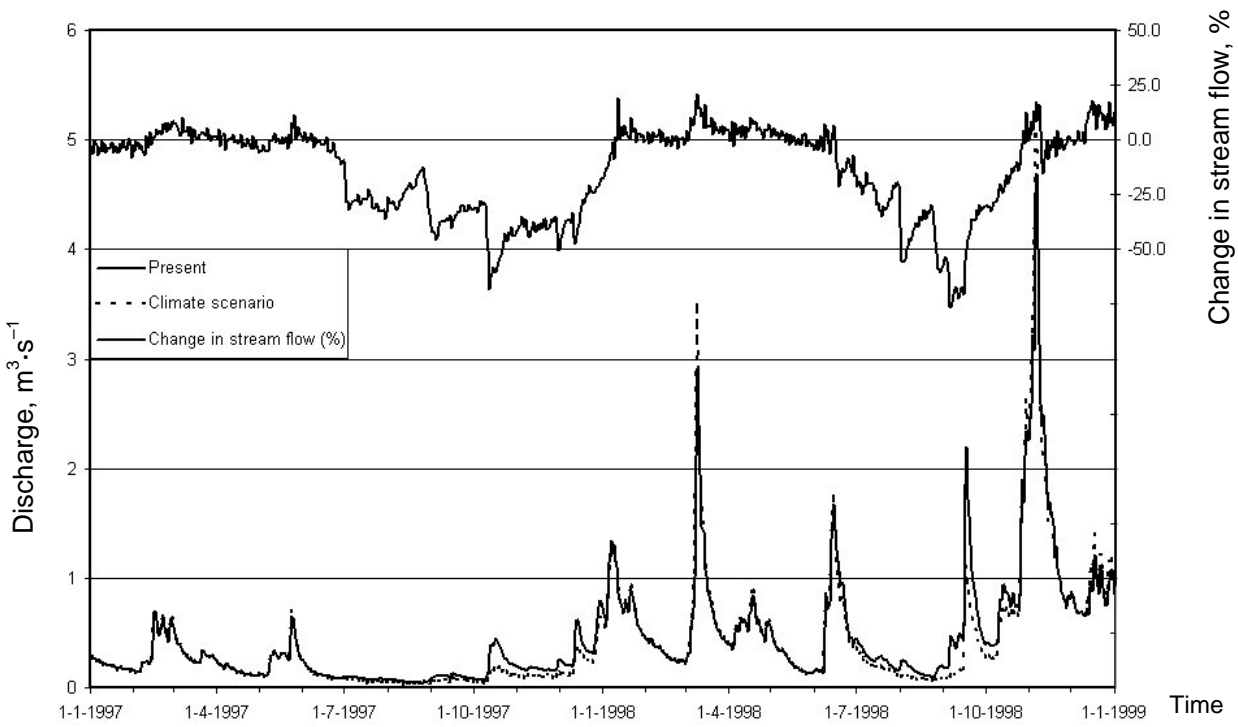

Fig. 6. Effect of climate change on stream flow for a sub-basin of $31 \mathrm{~km}^{2}$ 
The effect of the climate change on groundwater levels in the modelling area was moderate. In summer the lowest groundwater levels, averaged over the 5 years, are in the order of 6-15 cm lower, and in winter the high groundwater levels around $5 \mathrm{~cm}$ higher.

For the extreme peak flow occurring in November 1998 it was estimated that the increase in flow for the climate change scenario lasted around 6 days and this increase was estimated for the sub-basin to be $4 \mathrm{~mm}$ of water. This amount of water can be retained in the reed fields and in the wet forest.

\section{DISCUSSION AND CONCLUSIONS}

The European Water Framework Directive can have enormous consequences for agriculture in the Netherlands. In parts of the country agriculture should be taken out of production because the nutrient loads to the surface water system are far too high. Using reed fields is a possibility to improve the water quality and these areas can be used as well for water retention in order to prevent flooding downstream. The analysis carried out gives knowledge on the multifunctional use of such a system and tools will be developed for the hydrological feasibility of water storage and purifying reed lands in other parts of the Netherlands.

The model verification was limited to a short period, but the simulation results show that the models gives satisfactory estimates of the hydrological situation. The SIMGRO model was able to simulate stream flow for the main brook in the modelling area and groundwater levels on the estate. The hydrological analysis of the intake of water to the reed fields shows that the too dry conditions in summer on the estate can be easily reduced by the intake of water for the reed fields.

The climate in Europe is expected to become warmer and wetter during the coming 50 years, the temperature rises, and stream flow from regional water systems reduces in summer, but peak flows in winter will increase. Therefore the anticipated climate change results in more frequent flooding and mitigation measures are necessary to cope with the hydrological risk. For the Lankheet region a scenario study was conducted to quantify the increased risk, using a regional hydrological model to simulate the groundwater flow together with the water flow in a network of water courses. The analysis shows that peak flows in winter will increase by $10-$ $15 \%$. The low flows in summer will decrease considerable. This study shows that to adequately simulate the effect of climate change the model must be comprehensive and integrate surface water and groundwater, because the changes in precipitation and evapotranspiration will have a great effect on shallow groundwater conditions and on surface water levels.

Further analysis of the retention of water on the changes in stream flow will be carried out in the near future. Also the change in water quality on the estate will be investigated. 


\section{REFERENCES}

1. ERNST L.F., 1978. Drainage of undulating sandy soils with high groundwater tables. J. Hydrol. 39: $1-50$.

2. IPCC, 2007. Summary report and technical documents. Available at: http://ipcc-wg1.ucar.edu/wg1/ wg1-report.html

3. MuldER H.M., QuERNER E.P., 2007. Hydrological analysis for water conservation on the Lankheet estate (in Dutch). Draft Alterra report.

4. QUERNER E.P., 1997. Description and application of the combined surface and groundwater model MOGROW. J. Hydrol. 192: 158-188.

5. QUERNER E.P., 2002. Analysis of basin response resulting from climate change and mitigation measures. In: FRIEND 2002. Bridging the gaps between research and practice. Ed. H. van Lanen, S. Demuth. 4th Int. Conf. Friend, Cape Town, South Africa, March 2002. IAHS Publ., 274: 77-84.

6. QUERNER E.P., 2007. Water management measures analysed for Dutch basins to reduce flooding. J. Water Land Dev., 11: 45-58.

7. VAN BAKel P.J.T., 2006. Impact of the WFD on agriculture in the Netherlands and possible effectspecific hydrological measures: the Dutch approach. J. Water Land Dev. 10: 45-54.

8. Van Den Hurk B., Klein Tank A., Lenderink G., Ulden A. Van, Oldenborgh G.J. Van, Katsman C., Brink H. Van Den, Keller F., Bessembinder J., Burgers G., Komen G., HazeLEGER W., DrIJFHOUT S., 2006. KNMI Climate change scenarios 2006 for the Netherlands. KNMI, The Netherlands, KNMI Scientific Report WR 2006-01.

9. VAN Der Bolt F.J.E., LeEnders T.P., 2004. Aquarein: Impact of the European Water Framework Directive on agriculture, nature, recreation and fishery. Alterra publication, Wageningen, The Netherlands: 12.

10. Van Walsum P.E.V., Veldhuizen A.A., van Bakel P.J.T., van Der Bolt F.J.E., Dik P.E., GroeNENDIJK P., QUERNER E.P., SMIT M.F.R., 2004. SIMGRO 5.0.1, Theory and model implementation. Alterra-Report 913.1. Alterra, Wageningen, The Netherlands.

11. VEREIJKEN P., vAN dER WERF A., 2007. Experimental concept of water purification in reed fields. Available at: http://www.hetlankheet.nl/achtergronden.html

\section{STRESZCZENIE}

\section{Analiza hydrologiczna w obliczu skutków zmian klimatu i wymogów europejskiej Ramowej Dyrektywy Wodnej}

Słowa kluczowe: powodzie, przepływ wody, Ramowa Dyrektywa Wodna, retencja wody, wody gruntowe, wody powierzchniowe

Bardzo wilgotne ostatnie lata w Europie uświadomiły nam, że w bieżącym stuleciu należy podjąć kroki w celu zapobiegania powodziom. Pytanie, jak gospodarować wodami gruntowymi, aby zredukować przewidywany wzrost ryzyka hydrologicznego, pozostaje otwarte. Ponadto, jakość wód powierzchniowych w Holandii nie spełnia wymogów Ramowej Dyrektywy Wodnej. Trudno osiagnąć wymaganą poprawę, ponieważ niełatwo ograniczyć rozproszone ładunki pierwiastków biogennych z terenów rolniczych. Sytuacja ta wymaga innowacyjnych rozwiązań w odniesieniu do jakości wód powierzchniowych. Przedstawione badania koncen- 
trują się na oczyszczaniu wód w trzcinowisku i jednoczesnym wykorzystaniu go do ograniczenia skutków przewidywanych zmian klimatycznych. Z powodu braku eksperymentalnych danych w skali praktycznej, obsadzono trzciną 3 ha leśnego terenu w Lankheet we wschodniej Holandii. Celem tego projektu było następnie przetrzymanie oczyszczonych w ten sposób wód w wodach podziemnych celem ograniczenia skutków zmian klimatycznych. Dla takiej sytuacji hydrologicznej ustalono scenariusz badawczy z wykorzystaniem regionalnego modelu hydrologicznego, symulującego przepływ wód gruntowych w powiązaniu z przepływem wody w sieci cieków. Analiza wyników dostarczy danych do poznania wielofunkcyjnego wykorzystania takich systemów.

Reviewers:

Prof. Andrzej Ciepielowski

Dr. Marek Ślesicki 